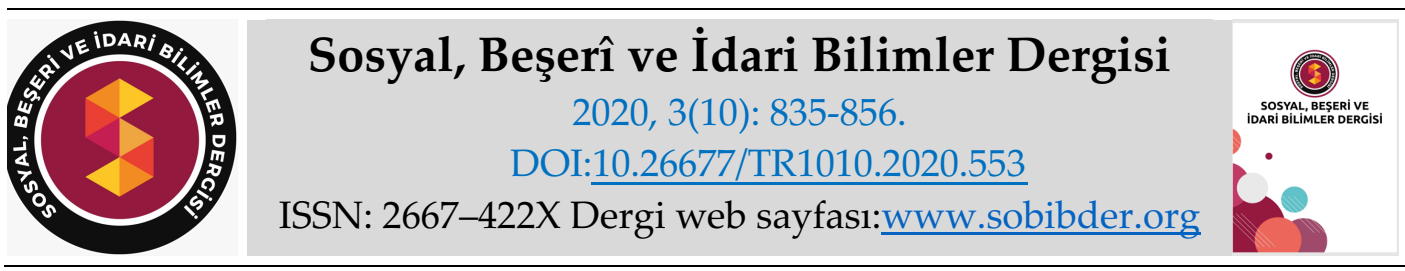

ARAȘTIRMA MAKALESI

\title{
Kariyer Stresinin Kariyer Kararlılı̆̆ı Üzerindeki Etkisinde Sosyal Ağ Desteğinin Aracılık Rolü: Gastronomi Öğrencileri Üzerine Bir Araştırma
}

Dr. Öğr. Üyesi Serdar ÇÖP, İstanbul Gelişim Üniversitesi, İktisadi ve İdari Bilimler Fakültesi,

İstanbul, e-posta: scop@gelisim.edu.tr

ORCID: https://orcid.org/0000-0002-1101-5676

$\ddot{O ̈ z}$

İnsanoğlunun doğal yaşam sürecinin her döneminde bir nebze de olsa belirsizlik bulunmaktadır. Her durum ve olay kendi içerisinde belirsizliklerle örülüdür. Bireysel seviyede, belirsizlik duyguları ve düşünceleri; çoğunlukla eş seçimi, bir ev satın almak veya kariyer hayatını şekillendirecek bir meslek seçimi ve iş değişiklikleri gibi önemli kararlar alırken yaşanmaktadır. Bireyler yaşadıkları belirsizlikleri azaltmak için bilgi edinme, tavsiye alma, araştırma yapma, psikolojik destek alma gibi birçok yönteme başvurmaktadır. Başvurulan yöntemlerin önemlilerinden bir tanesi de sosyal ağlarda sosyal destek beklentisidir. Sosyal ağlarda sosyal destek beklentisi insanların sosyal bir varlık olduğu ve doğada tek başına yaşamayacağı mutlaka sosyal, ekonomik, sözlü ve sözsüz şekilde etkileşim içerisine gireceği, belirsizlik durumlarında ise en yakınındaki bireyin sosyal ağları olarak tanımladığımız anne, baba, kardeş, akraba, meslektaş gibi aktörlerden mutlaka destek alma isteği duyacağ tezine dayanmaktadır. Bu çerçevede insanların yaşam felsefesinin temeli ilişkiler ağlar ve bu ağların oluşturduğu karşılıklı güven, sempati, yardımlaşma gibi kavramlar üzerine inşa edilmektedir. Kişilerin içinde bulundukları ruh hallerini, sevinçlerini, hüzünlerini, mutluluklarını ve başlarından geçen her türlü olayın yarattığı sebep ve sonuçları bu ortamlarda paylaşarak kendisi ile ilgilenildiğini gösteren ağ bağlantılarından maddi ve manevi destek beklemektedirler. Bu bağlamda çalışma; kariyer kararsızlığı ve stresi yaşayan bireylerin sosyal ağlarından aldıkları desteğin onların kariyer kararsızlığı ve stresini olumlu yönde etkilediğini ileri sürmektedir. Söz konusu savı araştırmak üzere İstanbul'daki Gastronomi bölümlerinde okuyan 196 öğrenciye anket uygulanmıştır. Araştırma ile ilgili olarak İstanbul Gelişim Üniversitesinden Etik kurallara uygun olduğuna dair rapor alınmıştır. Anketlerden elde edilen verilerin SPSS programında önce tanımlayıcı istatistikleri yapılmış daha sonra üç aşamalı hiyerarşik regresyon analizi yapılmıştır. Test sonuçlarına göre sosyal ağlarda sosyal destek beklentisinin kariyer belirsizliği ve stresi ile kariyer kararlılığı üzerinde pozitif etkisi olduğu ve ikisi arasında güçlü arabuluculuk rolü üstlendiği tespit edilmiştir.

Anahtar Kelimeler: Sosyal Ağlarda Destek Beklentisi, Kariyer Belirsizliği, Kariyer Kararlılı̆̆ı.

Makale Gönderme Tarihi: 02.07.2020

Makale Kabul Tarihi: 03.10.2020

\section{Önerilen Atıf:}

Çöp, S. (2020). Kariyer Stresinin Kariyer Kararlılığ Üzerindeki Etkisinde Sosyal Ağ Desteğinin Aracılık Rolü: Gastronomi Öğrencileri Üzerine Bir Araştırma, Sosyal, Beşeri ve İdari Bilimler Dergisi, 3(10): 835-856. (C) 2020 Sosyal, Beşerî ve İdari Bilimler Dergisi. 


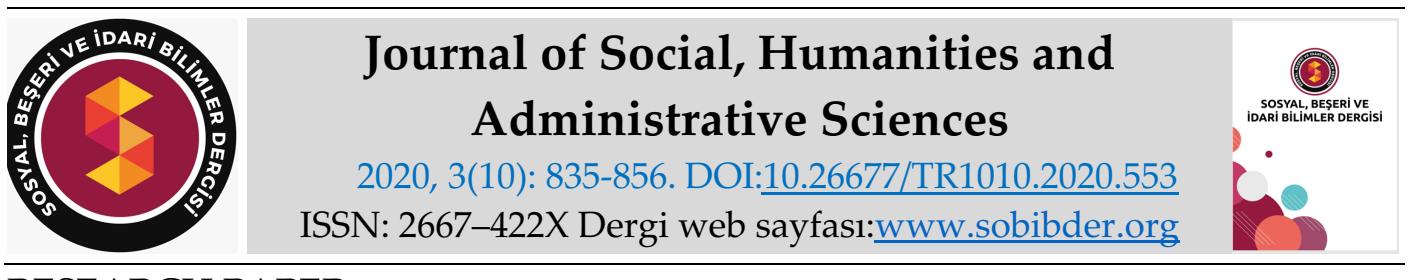

$\underline{\text { RESEARCH PAPER }}$

\title{
Mediation Role of Social Network Support on The Effects of Career Stress on Career Stability: A Research on the Gastronomy Students
}

Assistant Prof. Dr. Serdar ÇÖP, İstanbul Gelişim University, Faculty of Economics and Administrative Sciences, İstanbul, e-mail: scop@gelisim.edu.tr ORCID: https://orcid.org/0000-0002-1101-5676

\begin{abstract}
There is always some degree of uncertainty in human's natural life process. Every situation and event are covered with uncertainty in itself. This feeling of uncertainty is generally experienced while choosing a spouse, buying a new estate or thinking on career. An individual who has those kinds of uncertainties can appeal for some methods such as obtaining information, seeking advice and doing research to reduce them. Support expectation from social network is the most appealed one among those methods. In social networks, the expectation of social support is based on the thesis that in the case of uncertainty people will definitely want to get support from actors like family, relatives and friends defined as social networks, because they cannot interact alone in the nature as a social entity In this context, the basis of people's philosophy of life is based on the relationship networks and the concepts of mutual trust and sympathy that helped by these networks. Sharing their emotional situations, the moments of happiness and unhappiness with probable reasons and results of the events that they have experienced throughout their lives, people expect financial and emotional support from social networks. In this context, this study asserts the positive effects of the social networks on people's career stress and uncertainty. A questionnaire was applied to 196 students studying in the gastronomy departments in Istanbul to investigate thesis in question. The data obtained from the questionnaires was first described in the SPSS program and then hierarchical regression was analyzed within three stages. According to the results of the questionnaire, it was determined that the expectation of support in social networks has a positive effect on career stress and uncertainty in the process of career decision besides playing a strong mediation role between career stress and stability.
\end{abstract}

Keywords: Support Expectation in Social Networks, Career Uncertainty, Career Determination. Received: 02.07.2020

Accepted: 03.10.2020

\section{Suggested Citation:}

Çöp, S. (2020). Mediation Role of Social Network Support on The Effects of Career Stress on Career Stability: A Research on the Gastronomy Students, Journal of Social, Humanities and Administrative Sciences, 3(10): 835-856.

C 2020 Sosyal, Beşerî ve İdari Bilimler Dergisi. 


\section{Gíriş}

İşletmelerin insan kaynağı ihtiyaçları işletmenin kuruluş amaçları ve hedeflerine göre şekillenmektedir. Bir ürünün pazarlamasına yönelik olarak çalışan bir işletme daha çok reklam, satış teknikleri, iletişim gibi alanlarda uzmanlaşmış insan kaynağına ihtiyaç duyarken, üretim alanında faaliyet gösteren bir işletme daha çok mühendislik özellikleri ve yetenekleri yüksek olan insan kaynağına ihtiyaç duymaktadır. İhtiyaç duyulan insan kaynağı temini sağlandıktan sonra ise bireylerin yerine getirecekleri görev ve sorumluluklar belirlenerek, iş süreçleri esnasında ortaya çıkacak sorunları çözme yeteneklerini artırmak, karar verme süreçlerinde, yetki ve sorumluluk dengesini kurabilmek için yatay ve dikey hiyerarşik organizasyon yapıları ile bireylerin bir anlamda kariyer basamakları oluşturulmaktadır. Kariyer basamaklarına yerleştirilen çalışanların motivasyonunu artıracak ve bu sayede işletmenin kuruluş amaçlarını gerçekleştirmesine maksimum katkıyı sunacak, hizmet içi eğitimler, kurslar ve değişik kurumlarında verilen eğitimler düzenlenmektedir. Diğer bir anlatımla işletmelerde çalışanların yetki ve sorumlulukları, özlük hakları, hizmet içi eğitimleri, terfileri kısaca kariyer gelişimleri, aldıkları eğitimlere paralel şekilde oluşturulmaktadır. Bu sayede işletme amaç ve hedeflerini en iyi şekilde yerine getirecek "organizasyon yapısı" ve "insan kaynakları yapısı" oluşturulmaya çalışılmaktadır.

Ancak işletmelerin planladıkları insan kaynakları kariyer gelişimi ile çalışan bireylerin kariyer beklentileri bazı durumlarda örtüşmemektedir. Bu durum çalışanlarda hayal kırıklıklarına, geleceğe yönelik kariyer planlamasında nasıl bir yol izleyecekleri hususunda zihin karışıklığına ve kararsızlık içerisine sürüklenerek kariyer belirsizliğinden kaynaklı strese neden olmaktadır. Oysaki belirsizlik sadece insanların kariyer deneyimleri içinde karşılaştıkları bir durumdan ziyade yaşamın her aşamasında ortaya çıkabilecek, merkezi bir yaşam deneyimidir. Belirsizlik araştırmaları bu kapsamda genelde toplumsal, örgütsel ve bireysel düzeylere odaklanmış, sosyoloji, psikoloji, finans, örgütsel davranış ve strateji gibi birçok alanda araştırmacıların dikkatini çeken bir konu olmuştur. Belirsizlik temel bir insan deneyimi olmasına rağmen, kariyer alanındaki çalışmalar insanların kariyerlerinde oynadığı rolü büyük ölçüde göz ardı etmişlerdir. Hâlbuki belirsizlikler insanların kariyerlerinde mesleki davranışlarını, tutumlarını ve duygularını etkileyen temel bir faktördür (Roberts, 2006: 105). Ancak birçok kişi özellikle kariyerlerinin geleceği hususunda belirsizlik yaşadıklarında belirsizliği nasıl öngörülebilir bir duruma dönüştürecekleri konusunda tam bir bilgiye ve tecrübeye sahip değildir. Çalışmalar insanların kariyerleri ile ilgili yaşadıkları belirsizliklerle ilgili bilgi, görüş ve tavsiye almak üzere destek arayışı içerisine girdiğini bu desteği de en yakınlarındaki sosyal bağlantılarından beklediklerini göstermektedir.

Bu kapsamda kişiler kariyerleri ile ilgili kararlarında, ruhsal ve psikolojik yararlarının yanı sıra özellikle stresle ilişkili birçok hastalıkla pozitif ilişkisi olduğu tespit edilen, günümüzün en iyi iletişim aracı olan sosyal ağlarını bilgi, tavsiye, yeni bir iş bulmak, yeni kariyer fırsatları elde etmek ve destek almak amaçlı kullanabilmektedirler. Diğer bir anlatımla sosyal ağları sosyalleşme, arkadaş edinme, birey olarak çevrede daha görünür kılınma gibi birçok amacın yanında, kariyer belirsizliklerini ve stresini azaltma veya geleceklerini şekillendirmeye yönelik kariyer kararlılıklarını olgunlaştırmak amaçı kullanmaktadırlar. Bu bağlamda çalışma, zihinsel karmaşa içerisindeki ve kariyer belirsizliği yaşayan, bu nedenle kariyer stresi altındaki bireylerin, sosyal ağlarındaki çevrelerinden sosyal, psikolojik ve yol gösterici destek almalarının kariyer kararsızlığını ortadan kaldırmada etkin rol oynadığını ileri sürmektedir. Diğer bir ifadeyle bireylerin sosyal ağlarından aldıkları yeni iş teklifleri, fikir, düşünce ve psikolojik desteğin kariyer belirsizliklerini azaltarak gelecekteki kariyer kararlarının oluşumuna katkı sunduğunu iddia etmektedir. 
Kişilerin içerisinde bulunduğu olumsuz ruh halinden ve psikolojiden kurtulabilmesi için kendi kendine stresle mücadele, zor olan şeylerin üstesinden gelme konusunda azim ve kararlılığını göstermesi gerekmektedir. Ancak bazı durumlarda kişinin bu tür olumsuzlukların üzerinden gelmesi kendi çabasıyla mümkün olmamaktadır. Bu gibi durumlarda sosyal ağlarındaki kişilerin desteğine ihtiyaç duymaktadır.

$\mathrm{Bu}$ bağlamda belirsizliğin insanların kariyer deneyimini nasıl etkilediğinin anlaşılması kariyerlerin nasıl değiştiğinin ve bu değişikliklerin temelini oluşturan temel eğilimlerin incelenmesi önem arz etmektedir. Çalışma bu kapsamda, öncelikle belirsizliğin yaygınlığını, bireylerin kariyer kararları üzerindeki etkisini ortaya koyarak, kariyerdeki belirsizlik anlayışına ve kariyer kararlılığı ile olan etkileşimi ortaya koymayı amaçlamaktadır. İkinci olarak bireylerin kariyer stresini ve kararsızlığını ortadan kaldırarak, geleceğe yönelik daha öngörülebilir bilinçli ve kararlı bir kariyer gelişim planlaması ve düşüncesinin oluşmasına katkı sunan, günümüzde çalışanlar tarafından sıkça kullanılan sosyal ağların ve sosyal ağlardaki destek arayışlarının rolünü ortaya koymayı amaçlamaktadır. Üçüncü olarak ise çalışmanın ana savı olan "kariyer belirsizliğinin kariyer kararlılığın olumsuz olarak etkilediği ancak sosyal ă̆ desteğinin bu etkiyi azaltarak kariyer kararlılığının oluşmasına olumlu katkı sunduğu" savını yapılan anket uygulaması ve analiz sonuçları ile ortaya koymayı hedeflemektedir.

Sosyal bağlantılar aile ve akrabalardan başlayan yakın çevre sonrasında iş arkadaşlığı, meslektaşları vasıtasıyla genişleyen uzak çevreden oluşmaktadır. Bireyler yaşamlarını sürdürdükleri çevre içerisinde belirsizliğin hâkim olduğu durumlarla karşılaşmaktadır. Çalışma hayatının akış süreci içerisinde ortaya çıkan kariyer belirsizliği ve stresi de bunlardan bir tanesidir. Ancak belirsizlik ortamında bireyler yakın ve uzak çevrelerinin bilgi, tavsiye görüş öneri yanında maddi ve manevi anlamda desteğine ihtiyaç duymaktadırlar. Bireylerin sosyal ağlarından aldıkları yeni iş teklifleri, fikir, düşünce ve psikolojik desteğin kariyer belirsizliklerini azaltarak gelecekteki kariyer kararlarının oluşumuna katkı sunduğunu iddia etmektedir. Bu kapsamda çalışma bireylerin kariyer stresini ve kararsızlığını ortadan kaldırarak, geleceğe yönelik daha öngörülebilir bilinçli ve kararlı bir kariyer gelişim planlaması ve düşüncesinin oluşmasına katkı sağlayabilir. Günümüzde çalışanlar tarafından sıkça kullanılan sosyal ağların ve sosyal ağlardaki destek arayışlarının rolü hakkında akademisyenler, insan kaynakları yöneticileri ve özellikle kariyer belirsizliği ve stresi yaşayan çalışanlara yol gösterici bulgular sunabilir.

\section{KAVRAMSAL ÇERÇEVE}

\section{Sosyal Ağlar}

İnsanlar doğada tek başına yaşayabilen varlıklar değildir. Mutlaka çevresindeki diğer bireyler ile sosyal, ekonomik, sözlü ve sözsüz şekilde etkileşim içerisine girmektedirler. Bu onun içgüdüsel olarak, aile, akraba ve meslektaş gibi sosyal ağları olarak tanımlayabileceğimiz gruplar içerisinde kabul görme ve onların yardım ve desteğinden mahrum kalmama güdüsüyle hareket etmesinin sonucudur. Kişi sosyal ağları sayesinde karşı tarafa duygu ve düşüncelerini aktarmaya, onlarında bilgi, duygu, düşünce maddi ve manevi desteğini alma ihtiyacı duyarlar. Görüldüğü üzere insanların yaşam felsefesinin temeli ilişkiler ağlar ve bu ağların oluşturduğu karşılıklı güven, sempati, yardımlaşma gibi kavramlar üzerine inşa edilmektedir. Sosyal ağların oluşturduğu kişiler arası ilişkiler bireyin doğumundan itibaren en yakın çevresinden başlayarak her yıl genişleyen bir çember şeklinde ömür boyu devam etmektedir (Cüceloğlu, 1992). İnsanoğlunun bu davranış şekli ve sonuçları sosyal bilimlerde sosyal ağ kuramının temelini oluşturmaktadır. Sosyal ağ kuramının inceleme alanı, güç, güven, işten ayrılma, mikro seviyede liderlik gibi 
konulardır. Kuram insanların doğası gereği sosyal varlıklar olduğunu ve tek yaşayamayacaklarını savunur. Kuramın temel düşüncesi, insanların benzer şekilde davranış içerisinde olduğu, düşündüğü ve bu benzerlikler üzerinden ilişkiler kurduğu sosyal ağlarının olduğunu ileri sürmektedir. Berkman, (2000) sosyal ağları, bir bireyi çevreleyen sosyal ilişkilerin tümü olarak tanımlanmaktadır. Sahip olunan sosyal ağ bağlantıları insanları bazen birleştireceği gibi bazen de ayrıştırabilir. Park, Smith ve Dunkle, (2014)'ye göre de sosyal ă̆, bireylerin içinde bulunduğu sosyal ilişkilerin yapısının, işlevinin ve kalitesinin bir bileşimi olarak nitelendirilmektedir. Teknolojinin düşük olduğu toplumlarda veya dönemlerde bu ağlar komşuluk, arkadaşlık, arkadaşlık ilişkileri çerçevesinde oluşup dar bir coğrafyada şekillenirken, günümüzde gelişen teknolojinin sağladığı imkânlar ile ortaya çıkan sosyal medya araçları sayesinde geniş bir coğrafyada hatta dünya genelinde bağlantılar oluşturulabilmektedir. Bireyler sosyal bağlantıları sayesinde karşılıklı ilişkilerin ortaya çıkartı̆̆̆ kendi sosyal sermayelerini elde ederler ve gelecek planlarında edindikleri sosyal sermayeyi kullanırlar (Miles, 2016: 297). Diğer bir ifadeyle insanların sosyal sermayesinin kaynağını sosyal ağları oluşturmaktadır. Sosyal ağlara erişime bağlı olarak gelişen sosyal ilişkiler, sosyal faaliyetlere katılımı teşvik eder ve sosyal desteğe erişim sağlar, sırayla sosyal etkinliklere katılımı ve sosyal desteğe erişimi kolaylaştırır. Bundan dolayı sosyal ilişkiler hem sosyal ağlardan, sosyal aktiviteden hem de sosyal destekten etkilenir ve onları etkiler (Berkman, Glass, Brissette ve Seeman, 2000). Bu çerçevede araştırmacılar, sosyal ağ tipolojisini ortak sosyal bağları olan insan gruplarını türetmek için bir yaklaşım olarak kullanmaktadırlar (Doubova Dubova, Perez-Cuevas, Espinosa-Alarcon ve Flores-Hernandez, 2010).

Bir başka açıdan ise gelişen teknolojilerin ortaya çıkarttı̆̆ı yeni insan ilişkileri sosyal ă̆ tipolojisini her geçen gün değiştirmekte ve insanoğlunun yaşamına yeni sosyal ağ türleri ve çeşitleri katmaktadır. Bu ağlar kişinin en yakın çevresinden başlayarak küresel boyutta ilişkileri içine alan sosyal medya tabanlı gelişen sosyal ağlardır. Sosyal medya tabanlı bu ağlar kişiler arası iletişimin ve etkileşimin sınırlarını ve zaman boyutunu değiştirmiştir. Birey günün her saati ve dünyanın her tarafı ile sosyal ağ bağlantılarını sürdürme imkânına kavuşmuştur (Alav, 2012). Kişiler içinde bulundukları ruh hallerini, sevinçlerini, hüzünlerini, mutluluklarını ve başlarından geçen her türlü olayın yarattığı sebep ve sonuçları bu ortamlarda paylaşarak kendisi ile ilgilenildiğini gösteren ağ bağlantılarından maddi ve manevi destek beklemektedirler.

Literatürde sosyal izolasyon ve düşük sosyal destek seviyelerinin depresyonla ilişkili olduğu ortaya konulmuş, depresyon ve sosyal bağlantı faktörleri (temas sıklığı ve sosyal bağlantı kalitesi) arasındaki ilişki incelenmiştir. Araştırmanın sonuçlarına göre arkadaşları ve aile üyeleriyle yüksek seviyede ve kaliteli sosyal bağlantı kuranların daha az depresyon yaşama olasılığı olduğu belirtilmiş, depresyon için sosyal desteğin, özellikle de arkadaşların desteğinin kalitesinin önemli olduğu belirtilmiştir (Aliza, Mohammad, Cath ve Matthew, Tim 2017). Sosyal ağlar aynı zamanda zihinsel sağlık için de kritik öneme sahiptir, daha küçük ağlara, daha az kişilerarası ilişkiye veya daha düşük sosyal desteğe sahip bireylerin sürekli olarak depresyon ve kaygı yaşama oranlarının yüksek olduğu belirtilmektedir (Cacioppo, Hughes, Waite, Hawkley ve Thisted, 2006; Kawachi ve Berkman 2001). Sağlık alanında yapılan bir çalışmada büyük bir sosyal ağa sahip katılımcılara kıyasla, küçük bir sosyal ağa sahip olanların demografik, sosyoekonomik değişkenler, medeni durum, davranışsal ayarlamadan sonra inme (felç olma) riskinin daha yüksek olduğu ortaya konulmuştur (Nagayoshi, Mako, Everson, Susan, Iso, Hiroyasu, Mosley, Thomas, Rose, Kathryn, Lutsey ve Pamela 2014). Görüldüğü üzere literatürde sosyal ağlar ve sosyal ağların sağladığ1 desteğin sıkıntıya maruz kalan, belirsizlik yaşayan bireylerin sorunlarını çözmede merkezi öneme sahip olduğu kabul görmektedir (Uchino, 2009). Ancak kariyer belirsizliği ve kararsızlığ1 gibi durumlar da kişilerde stres ve kaygı yaratmaktadır. Sosyal ağlardaki destek beklentisinin 
kariyer belirsizliği üzerindeki etkilerini araştırmaya yönelik çok fazla sayıda araştırmaya rastlanılmamaktadır.

Sosyal ağ kuramı çerçevesinde yapılan çalışmaların genel sonuçları kişilerin sosyal ağlarının boyutu, kaynağı ve etkileşim sıklığı gibi yapısal bileşenlerinin, sosyal ilişkilerin algılanan kalitesi ve bunların duygusal veya kaygıları giderici, belirsizlikleri azaltıcı yönde destek sağlamaya yönelik önemli yordayıcılar olduğu yönündedir. Araştırma bu çerçevede insanların belirsizliğin yoğun olarak yaşandığı zor ve sıkıntılı süreçlerde sosyal ağlarındaki kişilerin imkân, yeteneklerinden destek alma eğiliminde olduğu ve onların kendilerine sağladığı olumlu psikolojik atmosferden faydalanabileceğini özellikle kariyer belirsizliği ve stresi yaşanan durumlarda onların yakın desteğini alarak kararsızlık durumunu kararlılığa dönüştürmede katkı sunacağını iddia etmektedir.

\section{Sosyal Ağlarda Destek Beklentisi}

Sosyal ağlar bireyler arasında bağlantıları ifade ederken, sosyal destek bu bağlantılardan bireyin kendisine olumlu yönde katkı sağlayabileceği etkileşimleri ifade eder. Sosyal ağlarda alınacak destekler samimi ve gizli ilişkilerin sonucunda oluşabileceği gibi duygusal destek biçimlerinde, tavsiye vermek gibi daha pragmatik ve maddi ve manevi yardım sağlayan araçsal destekleri içeren çok boyutlu bir yapıdadır (Tardy, 1985). Yapılan araştırmalar sosyal ağlardaki desteğin yapısal ve nitel yönlerine odaklanıldığını göstermektedir. Sosyal ağlarda cereyan eden faaliyetler sosyal ilişkilerin yapısal yönlerini temsil ederken, sosyal destek sosyal ilişkilerin işlevsel yönlerini temsil etmektedir (Kelly, Duff, Kelly, Joanna, McHugh, Sabina, Brian ve Loughrey, 2017). Sosyal ağların yapısal yönleri, ağın büyüklüğü, ağdaki üyeler arasındaki bağların gücü (iletişim sıklı̆̆ı) ile ilgilenirken, ağın kişinin ihtiyaçlarını ne ölçüde karşıladı̆̆ı, yalnızlı̆̆ı, psikolojik sıkıntıları ve kararsızlık durumlarında ağ çevresinin yardımları nitel yönleri oluşturduğu görülmektedir. Literatürde sosyal ağların hem niceliksel (ör., Kaç kişi ile yaşadığı, etkileşim sıklığı) hem de niteliksel (ör. İlişki kalitesi algıları) gibi özellikleri üzerindeki araştırmaları bir araya getirilmiştir (Chu, Saucier ve Hafner, 2010; Teo, Choi ve Valenstein, 2013). Bu çalışmalar hem etkileşim sıklığı hem de sosyal bağlantının kalitesi önemli olmakla birlikte ilişki kalitesinin sağlık açısından sonuçlarının stres ve belirsizlikler sonucu ortaya çıkan depresyon ile daha yakından ilişkili olduğunu tespit etmişlerdir.

Disiplinler arasında sosyal destek, sadece kişilerarası yaşamda değil aynı zamanda fiziksel ve ruh sağlığı için de önemli olarak kabul edilmektedir (Kim, 2014). Kişilerin sosyal ağlarından destek beklentisi doğası gereği çeşitli şekillerde olabilmektedir. Birincisi kişinin içinde bulunduğu belirsizliği ortadan kaldırmaya yönelik "bilgi desteği" şeklinde olabilir. Bilgi desteği kişiye fikirler ve eylemleri için öneri ve teklifler sunma, ortaya çıan yeni durumlara göre yeni hal tarzları geliştirme, ayrıntılı bilgilerin ve kaynakların sunulmasından oluşmaktadır. Bilgi desteği kişinin geleceğe yönelik kararlarını kesinleştirmesinde ve belirsizliğin yarattı̆̆ı problemlerini çözmesine yardımcı olabilir, iş ile ilgili stresi azaltabilir (Mac George, Feng, ve Burleson, 2012; Samter ve Gillihan, 2005). İkincisi malların, hizmetlerin, zamanın, enerjinin, paranın veya diğer kaynakların kullanımı yoluyla başkalarına yardımcı olacak teklifleri içeren maddi destektir (Gielen, McDonnell, Wu, O'Campo ve Faden, 2001). Bu bağlamda kişinin sosyal bağlantılarının sağlayacağı maddi destek, belirsizlik ortamında bireyin yaşam kalitesini yükseltmesine yardımcı olabilir.

Bireyler farklı sosyal destek biçimleri içerisinde daha yüksek sosyal statüdeki biriyle iletişim kurabilir. Yüksek sosyal statüdeki kişilerin zenginlik, güç ve diğer ağlara erişim gibi herkesin elde etmeyi arzuladığı imkânlara sahip olma olasılığı diğerlerine göre her zaman daha yüksektir (Cross ve Cummings, 2004). Ayrıca sosyal ağlardaki yüksek sosyal statüdeki gruplarının üyeleri, 
genellikle, düşük sosyal statüdeki gruplara göre daha fazla sosyal temasa, dolayısıyla daha yüksek ağ merkeziyetine sahiptirler (Sun, Kim ve Cameron, 2019). Bir başka açıdan ise sosyal ağlardaki desteğin gücü ve niteliği eğitim seviyesi ile ilişiklidir. Eğitim seviyesi arttıkça coğrafi olarak daha geniş, çeşitli ve yüksek seviyede sosyal ağlarla ilişki kurulurken, eğitim seviyesi azaldıkça, sosyal bağların ve temasların coğrafi olarak daha yakınlaştığı ağ çeşitliliğinin azaldığı görülmektedir (Ajrouch, Blandon ve Antonucci, 2005). Bu bağlamda kariyer stresi ve kararsızlığ1 içerisindeki kişilerin sosyal ağlarından alacakları desteğin gücü ve niteliği doğrudan kendi eğitim seviyeleri ve üyesi oldukları sosyal ağlardaki kişilerin eğitim seviyesi ve sosyal statülerinin seviyesi ile doğru orantılı şekilde arttığı söylenebilir. Kişilerin sosyal ağları vasıtasıyla iletişime geçtikleri kişilerin etki ve nüfuz alanından sağladığı destek ile kariyer belirsizliklerinin çözümüne katkı sağlayabilirler. Bu çerçevede çalışmanın kişilerin eğitim seviyesi ile sosyal ağ desteği ve kariyer belirsizliğini azaltma arasındaki ilişkileri ortaya çıkartması açısından literatüre sağlayacağı katkı önemlidir.

\section{Kariyer Stresi ve Belirsizliği}

Belirsizlik her yerde bulunur ve çoğunlukla her durum bir miktar belirsizlik içerir. Örneğin en basitinden kişiler zamanında varacak mıyım? Stresli bir gün geçirecek miyim? İşimi kaybeder miyim? Gibi günün olağan koşullarında doğal belirsizlik durumları yaşarlar. Bununla birlikte, bireysel düzeyde, en büyük belirsizlik duyguları ise çoğunlukla bir yaşam partneri seçmek, bir ev satın almak veya bir meslek seçmek gibi önemli kararlar alırken yaşanmaktadır (Sully de Luque ve Javidan, 2004). Sully de Luque ve meslektaşlarının da belirttiği gibi, bilimsel bilgiyi ilerletmek veya diğer gezegenleri keşfetmek gibi birçok insanın çabasını motive eden dürtülerin altında yatan neden belirsizliği azaltma arzusudur. Günlük yaşamlarında, bireyler hayatlarının öngörülebilirliğini arttırmak ve belirsizlik oluşumunu azaltmak için rutin alışkanlıklar oluştururlar. Bir şey öngörülebilir (yani kesin) veya tamamen öngörülemez olduğunda belirsizlik yaşanmaz. Bu nedenle, mutlak kesinlik ile mutlak öngörülemezdik arasında belirsizlik vardır. Benzer şekilde, bir kişinin kariyeri de tam olarak kesin değildir ve kesinlikle öngörülemez. Kariyer kararının kesinliğini azaltabilecek her zaman alternatif eylem yolları ve dikkate alınması gereken uygulamalar vardır ve bireyin kariyerine ilişkin deneyimi mutlak kesinlik ile mutlak öngörülemezlik arasındaki muğlak alanda şekillenmektedir (Roberts, 2006).

Bazı kişilere göre de kariyer maaş, terfi veya statü üçgeninde şekillenmektedir (Jaskolka, Beyer ve Trice 1985; Gattiker ve Larwood 1989) ve bunlar kariyerin objektif olarak gözlemlenebilir ve değerlendirilebilir ölçütleridir. Kariyer başarısını bu kriterlerle tanımladığımızda, hiyerarşik ilerleme, daha yüksek gelir ve genel olarak diğer kişilere göre daha fazla tanınma ve saygı görme algısı olarak görülebilir (Namhee ve Gary, 2008). Bu şekilde kariyerin nesnel olarak insan zihnindeki görünür tarifi ortaya konulduktan sonra kariyer kararsızlığ1 ve stresinin kaynağı da ortaya çıkmaktadır. Çünkü çalışan bireyi strese ve kararsızlığa sürükleyen temel unsurlar aslında kariyer olarak algıladığı maaş, terfi, statü, hiyerarşik olarak yükselme, daha yüksek gelir elde etme, tanınır olma ve daha fazla saygı görme gibi etkenlerdir. Kişi aslında kariyer kararını oluştururken bu hususlardan ne kadarını elde edip ne kadarını kaybedeceğinin sonuçları üzerinde yaptığı zihinsel muhasebesi aynı zamanda kariyer belirsizliğinin sebep olduğu kariyer stresinin kaynağını teşkil etmektedir. Bunlar kişinin kendi içsel durumunu ortaya çıkarttığı kariyer belirsizliği ve stres kaynağıdır.

Literatürde yapılan çalışmalarda bireylerin kariyer belirsizliği konusunda farklı anlayışlara sahip oldukları ve bunun sonraki kariyer davranışlarında belirgin farklılıklara yol açtığı belirtilmektedir (Trevor-Roberts, Parker, Sandberg ve Jorgen, (2019). Diğer bir anlatımla insanların belirgin olarak farklı kariyer davranışları ile sonuçlanan farklı belirsizlik algılarına ve 
anlamlandırmalarına sahip oldukları vurgulanmaktadır. Bu bağlamda kariyer belirsizliği üzerine yapılan çalışmada geçmişte düşük başarı gösteren ve sosyoekonomik geçmişi çok iyi olmayan ergenlerin kariyer beklentilerinde belirsizlik yaşama olasılıklarının daha yüksek olduğunu destekleyen sonuçlara ulaşılmıştır (Gutman, Leslie ve Schoon, 2012). Avusturyalı 51 genç üzerinde yapılan bir başka çalışmada ise gençlerin teknolojideki ilerlemenin yarattığ olumsuzluklar ve belirsizlikler karşısında iyi bir kariyer hikâyesi oluşturma konusunda yeteneklerinden emin oldukları tespit edilmiştir. Çalışmada teknolojik gelişmenin kariyer planlarını tehlikeye atma olasılığından kaçınamayan bir grubun ise kariyerlerini yeni koşullara göre biçimlendirme eğiliminde oldukları vurgulanmıştır (Skrbišs, Zlatko, Laughland ve Jacqueline, 2019). Örneğin literatürde 7418 kişi üzerinde yapılan çalışma sonuçları, benlik saygısı yüksek olan öğrencilerin kariyer belirsizliklerinin daha düşük olduğunu göstermektedir. Çalışma benliğin, öz saygının, kariyer belirsizliğinin farklılaşmasında önemli bir etken olduğu ortaya koymaktadır. (Lin, Shin-Huei, Wu, Chia-huei, Chen ve Lung, 2015). Bazı çalışmalarda kariyer kararsızlığı ile düşük benlik saygısı arasında anlamlı ve pozitif bir bağlantı olduğunu öne sürülmektedir (Creed, Prideaux ve Patton, 2005; Germeijs ve De Boeck, 2002; Santos, 2001; Shea, Ma, Yeh, Lee ve Pituc, 2009). Son yıllarda artan teknoloji ile birlikte tüm bireylerin yaşaminda önemli yer tutan sosyal ağların kariyer kararlılığını etkileyip etkilemediği etkiliyor ise hangi yönde ve nasıl etkilediği önemli bir konudur. Diğer bir anlatımla sosyal ağların bireyin kararlarının oluşumunda önemli bir etkiye sahip olduğu iddia edilmektedir. Kariyer belirsizliği ve stresi bireylerin sahip olduğu eğitim seviyesi, çalışma süresi, yaş gibi birçok demografik faktörlere göre farklılaştığı görülmektedir. Bu bağlamda çalışma kariyer belirsizliği ve stresindeki farklılaşmanın arkasındaki potansiyel nedenlerin ortaya konulması açısından önemlidir. Farklılaşmanın nedenlerini tam açıklayabilmek için kariyer belirsizliği ve stresini ortaya çıkartan nedenlerin iyi analiz edilmesi gerekmektedir. Kariyer belirsizliği ve stresini artıran faktörlerin başında teknolojik gelişmeler ve yapay zekâ uygulamaları, krizler, psikolojik bozukluklar gelmektedir.

Önümüzdeki yıllarda her alanda yaşanan dijitalleşme, yapay zekâ uygulamaları ve otomasyonun iş süreçlerini önemli ölçüde değiştirmesi beklenmektedir. Uygulamaların bazıları verimliliği artırırken aynı zamanda çalışanlara yeni kariyer fırsatları sunmaktadır. Diğer taraftan bazı işlerin ve kariyer basamaklarının da ortadan kalkmasına neden olmaktadır (Skrbiš vd., 2019). Bu bağlamda günümüzde artan teknolojik, ekonomik, sosyal ve çevresel hareketlilik iş dünyasına sürekli yeni iş kollarını katarken, beraberinde birçok mesleği ve kariyer basamağını da ortadan kaldırmaktadır. Ortadan kalkan her meslek veya iş kolu beraberinde çalışanların iş yaşamını ve kariyer basamaklarını sonlandırmakta veya daha üst basamaklara taşımaktadır. Kariyer basamağı sonlanan ve işini kaybeden her kişi doğal olarak geleceğe dönük kariyeri ve işi ile ilgili belirsizliklerden kaynaklı strese girebilmektedir. Ancak belirsizliğin insanların kariyerlerindeki rolü tam olarak anlaşılamamaktadır. Belirsizliği açıklayan teorilerde, bunu insanların kariyeri üzerinde olumsuz bir etki olarak göstermekte ve bu nedenle belirsizliğin azaltılarak bunlardan kaçınılması gerektiğine vurgu yapılmaktadır.

Kariyer belirsizliğinin başka bir etkeni ise küreselleşme ve teknolojideki gelişmelerin iş yeri kavramını ve çalışma hayatına değiştirmesidir. Bilgi ve iletişim teknolojilerindeki ilerlemeler ve daha fazla dijitalleşen sanayiye geçiş, tanımlanabilir öngörülebilir kurumsal kariyer yollarını günümüzde artık garanti etmemektedir (De Cuyper, De Witte ve Van, 2011; McElroy ve Weng, 2016). Kariyer yollarını yönlendirmek ve kariyer davranışlarında uyarlanabilir ve proaktif olmak için daha fazla sorumluluk sahibi bireylere ihtiyaç duyulmaktadır. (Hall ve Kahn, 2004). Diğer bir kariyer belirsizliği ve stresinin kaynağı genel anksiyete bozukluğudur. Genel anksiyete bozukluğu kişinin kaygı ve endişe ile birlikte 'ben daha aşağıyım' "yararsız biriyim” gibi olumsuz bilinçaltı inançlarından ve düşüncelerinden kaynaklanmaktadır. Kronik bir endişesi olan bireyin 
muhtemelen kendi benliği hakkında olumsuz temel inançları vardır. Sık endişe duyanlar, 'bu dünyada hayatta kalabilmek için her şeyi sıkı kontrol altında tutmalıyım' endişesi taşırlar ve dünya hakkında olumsuz inanışlara sahip olabilirler (örneğin dünya tehlikelidir) bu yüzden yüksek ücretli bir iş edinmeleri gerektiği yoksa ailelerinin ihtiyaçlarını karşılayamayacakları kaygısı taşırlar (Law, Ada, Amundson, Norman, Alden ve Lynn, 2014). Doğal olarak bu süreç kariyer kaygısı ve belirsizliğini beraberinde getirmekte kariyer kararlılığının oluşumunu olumsuz etkilemektedir. İş kaybı, iş bulma ve gelir değişikliğinin yarattı̆̆ uyumsuzluklarda kariyer belirsizliği ve stresini tetikleyen faktörlerdendir (Körner, Lchner, Pavlova ve Silbereisen, 2015).

Diğer bir kariyer belirsizliği kaynağ bölünmüş, esnek işgücü piyasası ve adaletsiz gelir dağılımı birleşimi, yeni nesil profesyonellerini eşi görülmemiş bir belirsizlik içerisine sokmaktadır (Cavalca, 2018). Krizler ve belirsizlikler birçok gencin lise veya üniversitelerden mezun olduktan sonra işgücüne girmede ve istihdam beklentileri üzerinde kalıcı olumsuz etkiler yaratmaktadır. Bu anlamda birçok lisans öğrencisi için, bir kariyer seçme ve hazırlama süreci belirsizlikle doludur ve birçok üniversite mezunu krizin ortaya çıkarttığı işsizlik artış oranları sayesinde genellikle üniversite diploması gerektirmeyen işlerde çalışmaktadırlar (Davis, Kimball ve Gould, 2015). Böylesi dönemlerde bir işe girmek oldukça zordur ve kariyer yolculuğuna ilişkin dikkatli kararlar, başarılı bir kariyer seçiminde önemli rol oynamaktadır. Bir kariyer yolu hakkında karar vermek, tartışmasız, genç bir yetişkinin en büyük kararlarından biridir ve çok fazla belirsizlik içerir. Kişinin Motivasyonu ve güdüleri genellikle belirsizliği azaltmak için bilgi ve destek arama ihtiyacı duyup duymadıkların belirler. Günümüz şartlarında kariyer arayışlarına bilgi ve destek sağlayacak en erişebilir ve kolay yöntem iletişim teknolojileri ve sosyal ağlar olmaktadır. Her ikisi kariyer keşfi ile ilgili belirsizliğin bir kısmını azaltmak için kolay erişilebilir kaynaklar gibi görünmektedir (Fetherston, Cherney ve Bunton, 2018). Ancak başarısı kişinin sosyal ağlarının nitelik ve niceliği ile birlikte kendisinin teknolojiye olan uyumuna bağlıdır. 2008 yılında yaşanan son ekonomik kriz ve durgunluk nedeniyle özellikle ABD'de İngiltere gibi gelişmiş ülkelerde durum daha karmaşık hale gelmiştir. Genç nüfus, her iki ülkede de işsizlik boyutunda ağır darbe almıştır (Danziger ve Ratner, 2010). Gençler artık tam zamanlı eğitime devam etmenin yanı sıra rekabetçi bir işgücü piyasasında başarılı olmak için resmi anlamda kendilerine yeni nitelikler elde etmek için artan bir baskı ile karşı karşıya kalmaktadırlar (Bynner, 2005). Bu durumun doğal sonucu olarak kişiler geleceklerini şekillendirecek meslek ve kariyer planlamalarında kendilerini baskı altında hissetme ve strese girmelerine neden olmaktadır.

Yukarıda açıklanan huşulardan anlaşıldığı üzere özellikle kariyer basamağının ilk evresinde olan genç bireyler günümüzde eğitim ve kariyer fırsatları konusunda büyük bir belirsizlikle karşı karşıya kalmaktadırlar (Kalleberg vd., 2000, Mills ve Blossfeld, 2003). Küreselleşme ile birlikte yaşanan iş gücü hareketleri, özellikle ergenler ve genç yetişkinlerin iş ve kariyer süreçlerini zorlaştırmaktadır (Bynner, 2005). Bu bağlamda en önemli sorun kariyer belirsizliği ve stresi ile nasıl baş edileceğidir. Pryor ve Bright, (2011),'in kaos kariyer teorisi kariyer belirsizliği ve stresi ile baş etme konusuna açıklık getirmektedir. Teoriye göre dünya sürekli değişim içerisindedir ve öngörülemezliklerle doludur. Mesleki değişimlere bağlı olarak kariyer planlaması yapılırken ortaya çıkacak belirsizliklerin yıkıcı etkisini azaltmak için sadece planlamalara göre hareket etmek yerine, geleceğe yönelik değişimleri kabullenmek, içselleştirmek ve değişimlerin ortaya çıkartacağı olasılıklara göre yaratııı fikirlere de üretmek gerekmektedir (Law vd., 2014). Özellikle ekonomik krizlerin yoğun hissedildiği durumlarda işletmelerin krizin etkisini azaltmaya yönelik maliyetleri azaltıcı etkisi nedeniyle yoğun şekilde işten çıkarma yöntemine başvurmaları, çalışanlar arasında büyük bir belirsizlik ve strese yol açmakta, çalışan memnuniyetini, psikolojik refahı ve iş kariyer beklentilerini aşındırmaktadır (Reinardy, 2011). Krizin hâkim olduğu 
belirsizlik ortamında organizasyonun yeni şartlara uyumunu sağlamak ve çalışanların kariyer beklentilerini ve iş belirsizliğini yönetmek, insan kaynakları açısından hayati öneme sahip bir zorluk haline gelmektedir (Goyanes, Manuel ve Rodríguez-Gómez, 2018). Çünkü kaybedeceği her çalışanın işler düzeldiğinde yerine yenisini koyması eskisini elde tutmanın maliyetinden daha fazla olacak sarsılan güveni tesis etmesi ise çok daha zor olacaktır.

\section{Kariyer Kararlılığ1}

Bireyler iş dünyasının şekillendirdiği sosyo ekonomik dünya içerisinde yaşamlarını sürdürürken kendilerini en çok etkileyen faktörlerin başında kariyerlerine yönelik aldıkları kararlar gelmektedir. Yapılan çalışmalarda bireyin yaşamdan aldığı haz ve mutluluk ile kariyer yolculuğu ve meslek seçimleri arasında yakın bir ilişki olduğunu belirtilmektedir (Greenhaus Callanan ve Kaplan, 1995; Lounsbury, Tatum, Chambers, Owens ve Gibson, 1999; Uthayakumar, Schimmack, Hartung ve Rogers, 2010). Kişinin çalışma hayatı süresince herhangi bir organizasyon içerisinde yerine getirilmesi gereken görevleri ifa edebilmek için kendisine verilen sorumlulukları yetkileri ve bunlardan kaynaklı mevki, makamları kendi yetenekleri, aldığı eğitimleri ve iş yapma arzusu ile birleştirerek elde ettiği konumlar bireyin kariyer basamaklarını oluşturmaktadır (Aytaç, 2005: 6). Kişinin elde ettiği konum ve pozisyonu seçmekten dolayı duyduğu memnuniyet, bağlılık ve motivasyonu ise kariyer kararlılığını göstermektedir. Kariyer kararlılığı literatürde "sosyal bilişsel kuram" içerisinde ele alınmaktadır. Kuramın temel savı ise kişilerin kariyer kararlarını her ne kadar kendisi vermiş olsa da çevrenin de önemli bir faktör olduğu yönündedir (Restubog Florentino ve Garcia, 2010: 187). Literatürde yapılan çalışmalar ise kariyer kararlılı̆̆ daha çok meslek seçimi, kişinin öz yeterliliği, eğitim seviyesi, kişilik ve tatmin, örgütsel bağlllık, sosyal destek gibi konular ile ilişkilendirildiği görülmektedir. Konu ile ilgili olarak 303 Hırvat öğrencinin kariyer kararı, öz-yeterlik, duygusal istikrar ve duygusal yeterlilik ile ilgili endişelerinin ölçüldüğü çalışma sonuçlarına göre duygusal istikrar ve öz-yeterliliğin kariyer kararlılığının istatistiksel olarak anlamlı bir yordayıcısı olduğunu ortaya koymuştur (Bubic ve Ivanisevic, 2016). Yapılan başka bir çalışmada belirli demografik değişkenlerdeki (yaş, iş tecrübesi, istihdam düzeyi, cinsiyet, iş türü ve eğitim düzeyi) farklılıklara bakarak kariyer yöneliminin istikrarlı olup olmadığını ve baskın türlerin olup olmadığını araştırmıştır. Bulgular, kariyer istikrarının yaşa, iş deneyiminin uzunluğuna ve istihdam düzeyine göre farklılaştığını, kariyer başarı yönelimlerinin ise sadece eğitim düzeyine bağlı olduğunu göstermektedir (Namhee ve Gary, 2008).

Bireylerin kariyer ile ilgili kararlarını birçok unsur etkilemektedir. Bu unsurlar kişinin meslekten beklentileri, maddi manevi ihtiyaçlarını karşılama derecesi, kendi iş yapma ve çalışma değerleri ile örtüşüp örtüşmediği, kişisel yetenek ve becerileri, kendisine verilen rollerin ve çalışma stillerinin kişilik özellikleri ile uyuşup uyuşmadığı gibi hususlardır. Bunların yanı sıra iş ortamındaki ekip çalışması, analitik yetenekleri kullanma seviyesi, çalışma ortamının (iç mekân ile dış mekân) uyumu, sağlanan gelir, bağımsızlık derecesi, el becerisi, çalışma saatlerinin esnekliği, çalışma süresi ve diğer insanlara yardım etme düzeyi gibi faktörler kariyer kararlarının oluşumuna etki edebilmektedir (Gati ve Gutentag, 2015). Yapılan çalışmalarda bireylerin meslekleri ile ilgili hususları değerlendirirken mesleğin sağladığı maddi çıkarlar dışında kariyer yönleri açısından dikkate aldıklarını göstermiştir (Gati, 1998). Ayrıca, kişilerin çıkarlar yerine Kişi-Çevre uyumu ve iş tatminine daha fazla odaklandıkları görülmüştür (Gati, Garty ve Fassa, 1996). Başka bir çalışmada ise ulusal düzeyde İngilizce kolejde öğrenim gören 6.000 'den fazla örneklemde öğrenciler arasında bilim, teknoloji, mühendislik, matematik alanındaki kariyerlerine olan ilginin nasıl değiştiği araştırılmıştır. Araştırma sonuçlarına göre kariyer kararlarının verilmesinde cinsiyetin önemli bir faktör olduğu belirlenmiş, erkeklerin özellikle 
mühendisliğe çok daha fazla ilgi gösterirken, kadınların lise yıllarında sağlık ve tıp kariyerlerine daha fazla ilgi duydukları tespit edilmiştir (Sadler vd., 2012).

Kariyer kararlarının istikrarına yönelik araştırmalarda, ailenin etkisi ve motivasyonun yanı sıra kişilik özelliklerinin de önemli bir rol oynadığını göstermektedir. Kişilik özellikleri mizaç özellikleri veya davranış stilleri kişinin yetişkinlik döneminde, ergenlik döneminde veya genç olup olmamasına veya yaşlılık döneminde olmasına göre farklılık göstermektedir. Bununla birlikte, kişilik ve kariyer uyumu arasındaki ilişkiler çift yönlüdür ve kişilik özellikleri iş ortamı dahil yaşam içerisindeki olayları etkileyebilmekte ve onlardan etkilenebilmektedir (Shiner, Caspi, 2012; Specht, Egloff ve Schmukle, 2011). Son 100 yıllık kişilik araştırmaları kişilik özelliklerinin bireyi aile yaşamından, akademik başarısına, iş seçiminden, eş seçimine, stres direnci ve başa çıkmadan, tükenmişlik duygusuna, mesleki seçimden kariyer kararlarının alınmasına kadar birçok alanda etkin rol oynadığına dair kanıtlar sunmaktadır (Jokela, Hintsa, Hintsanen, Keltikangas-Jarvinen, 2010; Connor ve Flaschbart, 2007). Günümüzde bireylerin kişilik özelliklerini ortaya çıkartarak, belirli bir ölçüde, insanların belirli yaşam alanlarında nasıl yaşayacaklarını ve nasıl davranacakları tahmin dahi edilebilmektedir. Görüldüğü üzere, kişilik özelliklerinin başta kariyer kararlarının oluşumu olmak üzere yaşamın gelecekteki seyrini büyük ölçüde belirlediğini söyleyebiliriz.

Kariyer kararlılığına etki eden faktörlerden bir diğeri kişinin etkileşim içerisinde bulunduğu çalışma ortamında kendilerinin yaşadığı değişim süreci, mesleği hakkında edindiği bilgi, tecrübe ve yeteneklerdir. Derr (1986) bu konuda insanların kariyer yönelimlerini iş ortamındaki etkileşim yoluyla değiştirebileceğini öne sürülmektedir. Krumboltz (1979), insanlar ve çevreleri arasında her zaman dinamik bir etkileşim olduğunu iddia etmiştir ve insanlar temel ihtiyaçlarını, değerlerini ve dış uyaranlara, yeni bilgilere, farklı düşüncelere ve duygulara cevap verme yeteneğini değiştirebileceğini savunmuştur. Miguel (1993), insanlar büyüdükçe kişisel kariyer yönelimlerinin farklı olduğunu tespit etmiştir. Loughlin ve Barling (2001) genç işçilerin çalışma değerlerinin, tutumlarının ve davranışlarının eski nesilden farklı olduğunu belirtmektedirler. Doorewaard, Hendrickx ve Verschuren (2004) yaşın para yönelimi üzerinde anlamlı bir etkisi olmadığını vurgulamaktadır (Aktaran, Namhee ve Gary 2008). Bu çalışmalar kariyer kararlarının oluşmasında çevre, çalışma süresi, yaş ve tecrübe gibi unsurların önemli bir değişken olduğunu göstermektedir. Bu bağlamda çalışma kariyer kararlılığının kişinin yaşı, mesleki tecrübesine göre nasıl değişim gösterdiğini ortaya koyması açısından önemlidir.

Literatürden de anlaşıldığı üzere kariyer yolculuğu öncelikle meslek seçimi ile başlamaktadır ve meslek seçimi de bireyin eğitimi, sosyo kültürel çevresi, kişisel özelliği, psikolojik yapısı, kişisel yetenekleri gibi birçok faktörden etkilenmektedir (Alkan, 2014: 63). Ancak kişiler kariyer yolculuğu esnasında bazen kendilerinden bazen çevresel koşullardan kaynaklı belirsizlik içerisine düşmektedirler. Kararsızlık halini öngörülebilir planlanmış kararlar haline dönüştürmek kişinin kendisini kararsızlığa düşüren içsel ve çevresel etkenleri ortadan kaldırma yeteneğine ve becerişine bağhıdır. Bazen bunu başarmak kişinin imkân ve yetenekleri üzerinde bir çabayı gerekli kıldığından çevresinden özellikle de sosyal ağlarındaki kişilerden bilgi, tavsiye, görüş, olmak üzere maddi ve manevi destek beklentisi içerisine girerler. Çalışma bu bağlamda sosyal destek beklentisinin kişilerin kariyer stresini azaltama da ve kariyer belirsizliklerini ortadan kaldırmada etkin rol oynadığını ileri sürmektedir.

\section{YÖNTEM}

Çalışma ile ilgili olarak İstanbul Gelişim Üniversitesi'nin (İGÜ) 30.04.2020 tarihli 2020-12-19 sayılı kararı ile "etik kurul raporu İGü etik kurulu yönergesinin ilgili maddelerine bağh olarak yapılan değerlendirmede etik kurallara uygun olduğu" belirlenmiştir. Literatürde yapılan araştırma 
sonuçlarına göre inşa edilen modelin kurgusunda kariyer belirsizliğinin kariyer kararlılı̆̆ını olumsuz olarak etkilediği düşünülmektedir. Ancak günümüzün gelişen teknolojisi sayesinde dünya nüfusunun büyük bir çoğunluğunun gündelik yaşamına giren sosyal ağların ve bu ağlardan sağlanacak desteğin kariyer kararlılı̆̆ının oluşmasına olumlu katkı sunacağı ve kariyer stresinin olumsuz etkisini azaltıcı rol oynayacağ değerlendirilmektedir. Diğer bir ifadeyle sosyal ağlar üzerinden sağlanan fikirsel, psikolojik, maddi, manevi her türlü desteğin çift yönlü olarak hem kariyer stresini olumlu etkilediği hem de kariyer kararlılığının oluşumuna olumlu katkı sunduğu iddia edilmektedir. Bu bağlamda çalışmanın modeli Şekil 1.'deki gibi kurgulanmış ve aşağıdaki hipotezler oluşturulmuştur. Çalışmada aşağıda özellikleri belirtilen ölçeklerden oluşan 40 soruluk anketin uygulanmasından elde edilen sonuçlara göre hipotezlerin geçerliliğinin test edilmesi amaçlanmıştır.

\section{Araştırma Modeli ve Hipotezler}

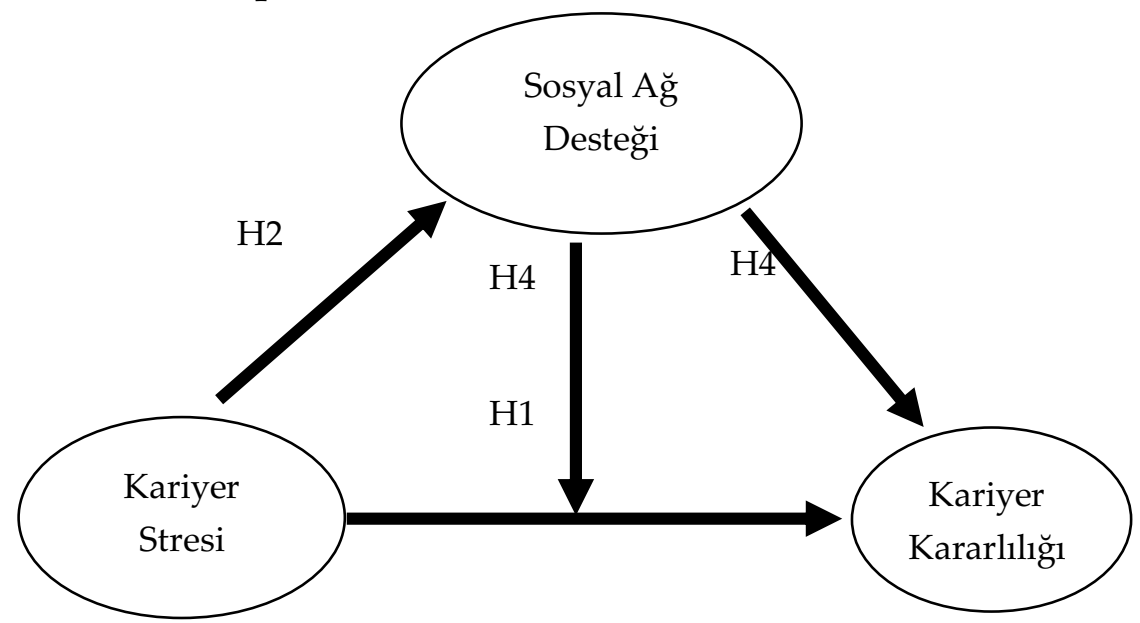

Şekil 1. Araştırma Modeli

H1: Kariyer stresi kariyer kararlılığını etkilemektedir.

$\mathbf{H}_{2}$ : Kariyer stresi sosyal ağ desteğini etkilemektedir.

$\mathbf{H}_{3}$ : Sosyal ağ desteği kariyer kararlılığını etkilemektedir.

H4: Kariyer stresinin kariyer kararlılığını etkilemesinde sosyal ağ desteğinin aracılık rolü vardır.

\section{Evren ve Örneklem}

Araştırmanın katılımcıları İstanbul'da Gastronomi bölümünün bulunduğu 21 Üniversitede okuyan öğrencilerden oluşmaktadır. 1193 kontenjanın bulunduğu Gastronomi bölümü öğrencilerinden destek istenmiştir. Araştırmaya katılan öğrencilerin verdiği cevaplara göre 193 anket değerlendirmeye alınmıştır.

\section{Veri Toplama Süreci ve Araştırmada Kullanılan Ölçekler}

Araştırmanın hipotezleri ve modeli çerçevesinde, kariyer kararlılığının, sosyal ağ desteğinin ve kariyer stresinin ölçülmesine yönelik verilerin toplanmasında anket tekniğinden faydalanılmıştır. Sosyal ağ destek beklentisi aracı değişken olarak belirlenmiş ve tek faktör 14 soru ile bağımlı değişken kariyer kararlılığı tek faktör 6 soru ile kariyer stresi ise üç alt faktörde 
(Kariyer Belirsizliği ve Bilgi Eksikliği 10 soru, Dışsal Çatışma 4 soru, İş Bulma Baskısı 6 soru) 20 soru ile ölçülmüştür. Katılımcıların yukarda belirtilen konulardaki algı seviyelerini ölçmek için toplam 44 sorudan oluşan "Tamamen katılıyorum (5)" "Hiç katılmıyorum (1)" aralığından oluşan 5’li Likert tipi anket uygulanmıştır.

Araştırmada Sosyal Ağlarda Sosyal Destek Beklentisini ölçmek için Uzakgiden ve Erözkan, (2019)'ın geçerlilik, güvenilirlik ve faktör yüklerini inceledikleri bulgular sonucunda "psikoloji ve eğitim alanında kullanılabilecek, geçerlik ve güvenilirlik özelliklerine sahip olduğunu" belirttikleri ölçek kullanılmıştır.

Kariyer kararlılığı ölçmek için Lounsbury vd. (1999)'nun geliştirdiği bir alt boyut ve 6 sorudan oluşan ölçeğin Türkçeye uyarlanmış hali kullanılmış, ölçeğin iç tutarlılık katsayısı 0.95 olarak tespit edilmiştir. Akçakanat ve Uzunbacak, (2019:161)' tarafından Türkçeye uyarlanması ve güvenilirlik analizleri yapılmıştır. Analiz sonuçlarına göre ölçeğin "psikometrik özellikleri bakımından yeterli olduğu ve Türk kültüründe kariyer kararlığı tutumunu ölçmede kullanılmasının uygun olduğu" belirtmişlerdir. Yapı geçerliliği Lounsbury ve Gibson (2002) ile Lounsbury vd., (2005) tarafından da sınanmıştır.

Kariyer Stresini ölçmek için, Choi ve arkadaşları (2011) tarafından 20 soru, kariyer belirsizliği, bilgi eksikliği, iş bulma baskısı ve dışsal çatışma olmak üzere 4 alt boyuttan oluşan Özden ve Berk, (2017) tarafından Türkçeye uyarlanan ve Psikometrik Özelliklerinin Sınanması sonucunda "güvenilir bir ölçme aracı olarak kullanılabileceğini" tespit ettikleri ölçek kullanılmıştır.

\section{Verilerin Analizi}

Araştırmaya katılan öğrencilerin anketlere verdikleri cevaplar SPSS paket programına aktarılmıştır. Ankete ilişkin verilerin sisteme işlenmesi ile güvenirlilik testi için iç tutarlılık düzeylerine bakılmıştır. Cronbach Alpha katsayısı sosyal bilimler açısından yüksek değerler içerisindedir. Güvenirlilik testinden sonra ortalama değerlere bakılmıştır. Ardından araştırmanın ana konusu olan hipotezlerin testi için regresyon analizi yapılmıştır. Aracılık testi için üç aşamalı regresyon analizi gerçekleştirilmiştir. Öncelikle çalışmanın bağımsız değişkeni olan kariyer stresi ve belirsizliğinin bağımlı değişken olan kariyer kararlılığı üzerindeki etkisi, sonra aracı değişken olan sosyal destek beklentisinin etkisi için hiyerarşik regresyon analizi gerçekleştirilmiştir.

\section{BULGULAR ve TARTIŞMA}

Araştırmaya katılan gastronomi bölümü öğrencilerinin verdiği yanıtlara göre ortalama, standart sapma değerleri aşağıdaki tabloda yer almaktadır:

Tablo 1. Araştırmaya Katılanların Kariyer Stresi, Kariyer Kararlılığı ve Sosyal Ağ Desteğine İlişkin Ortalama Değerler ve Standart Sapma

\begin{tabular}{|l|l|l|l|}
\hline & $\mathrm{n}$ & $\bar{x}$ & s. s. \\
\hline Kariyer Stresi & 193 & 3,617 & 1,26 \\
\hline Kariyer Kararlıı̆̆ı & 193 & 3,510 & 1,11 \\
\hline Sosyal Ă̆ Desteği & 193 & 3,754 & 1,01 \\
\hline
\end{tabular}


Araştırma temel değişkenleri olan kariyer stresinin, kariyer kararlılı̆̆ının ve sosyal ağ destek beklentisinin ortalamaları ile standart sapma değerleri Tablo 1'de verilmektedir. Elde edilen bulgulara göre kariyer stresi için ortalama değer 3,61; kariyer kararlılığı için ortalama değer 3,51; sosyal ağ desteği için ortalama değer 3,75 olarak belirlenmiştir. Likert ölçeğine göre sorulara verilen yanıtlar (5) kesinlikle katılıyorum, (4) katılıyorum, (3) ne katılıyorum ne katılmıyorum, (2) katılmıyorum, (1) kesinlikle katılmıyorum, şeklinde kodlanmıştır. Katılımcıların verdiği cevapların aritmetik ortalama sonuçları, standart sapmalarda dikkate alınarak değerlendirildiğinde; i) katılımcıların Likert ölçeğine göre değişkenler ile ilgili eğilimleri tüm değişkenlerin 3,5 ile 4'e arası dar bir değer aralığında kümelendiği gözlemlenmektedir. ii) Katılımcların büyük çoğunluğunun kariyer stresi, kariyer kararlılığı ve sosyal ağ desteği algılarının belirsizliği ifade eden (3) ne katılıyorum ne katılmıyorum ile (4) katılıyorum, arasında yoğunlaştığı görülmekte bu sonuç katılımcılarda belirsizlik ve kararsızlığın yoğun olarak algılandığı sonucunu güçlendirmektedir. iii) İstatistiki anlamda standart sapma; bir örneklem içerisinde toplanan verilerin teker teker her birisinin aritmetik ortalamaya ne kadar uzaklıkta olduğunu diğer bir ifadeyle verilen cevapların ortalamadan ne kadar uzaklıkta bir dağılım gösterdiğini ölçmektedir. Standart sapmanın büyüklüğü dağılımın yüksek olduğunu göstermektedir. Ortalama ve standart sapma birlikte değerlendirildiğinde en yüksek ortalamanın $(\bar{x}=3,754)$ ve en düşük düşük standart sapmanın (s.s. 1.01) sosyal ağ desteğinde olduğu görülmektedir. Standart sapmanın düşük ortalamanın 4'e (katılıyorum) yakın olması katılımcıların daha istikrarlı olarak sosyal ağları destek amaçlı kullandıklarının bir göstergesi olabilir.

Tablo 2. Kariyer Stresi ile Kariyer Kararlılığı Arasında Sosyal Ağ Desteğinin Aracllık Rolünün Tespitine Yönelik Hiyerarşik Regresyon Analizi Sonuçları

\begin{tabular}{|c|c|c|c|c|c|c|c|}
\hline $\begin{array}{l}\text { Bağımlı } \\
\text { Değişken }\end{array}$ & $\begin{array}{l}\text { Bağımsız } \\
\text { Değişken }\end{array}$ & B & $\begin{array}{l}\text { St. } \\
\text { Hata }\end{array}$ & $\beta$ & $\mathbf{t}$ & $\mathbf{p}$ & $\mathbf{R}^{2}$ \\
\hline \multirow{2}{*}{ Kariyer Kararlılığı } & Sabit & 0,744 & 0,124 & - & 6,004 & $0,000^{*}$ & \multirow[b]{2}{*}{0,745} \\
\hline & $\begin{array}{l}\text { Kariyer } \\
\text { Stresi } \\
\end{array}$ & $-0,765$ & 0,032 & $-0,823$ & 23,633 & $0,000^{*}$ & \\
\hline \multirow[b]{2}{*}{ 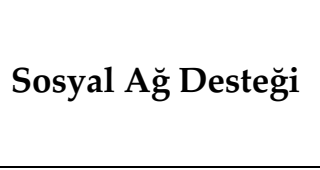 } & Sabit & 0,648 & 0,225 & - & 2,881 & $0,000^{*}$ & \multirow[b]{2}{*}{0,477} \\
\hline & $\begin{array}{l}\text { Kariyer } \\
\text { Stresi } \\
\end{array}$ & $-0,763$ & 0,058 & $-0,690$ & 13,18 & $0,000^{*}$ & \\
\hline \multirow{3}{*}{ Kariyer Kararlılığı } & Sabit & 1,190 & 0,153 & - & 7,765 & $0,000^{*}$ & \multirow{3}{*}{0,770} \\
\hline & $\begin{array}{l}\text { Kariyer } \\
\text { Stresi }\end{array}$ & $-1,032$ & 0,066 & $-1,165$ & 15,585 & $0,000^{*}$ & \\
\hline & $\begin{array}{l}\text { Sosyal A } \breve{g} \\
\text { Desteği }\end{array}$ & 0,376 & 0,083 & 0,341 & 4,559 & $0,000^{*}$ & \\
\hline
\end{tabular}

Kariyer stresi ile kariyer kararlılığı arasında sosyal ağ desteğinin aracılık rolünün tespiti için Baron ve Kenny (1986) tarafından ortaya atılan üç aşamalı hiyerarşik regresyon analizi gerçekleştirilmiştir. Illk aşamada birinci hipotez testi için ilk sırada yer alan kariyer stresi bağımsız değişken, kariyer kararlılığı bağımlı değişken olarak regresyon analizine tabi tutulmuştur. Bulgular değerlendirildiğinde kariyer stresinin kariyer kararlılı̆̆ını negatif etkilediği $(\beta=-0,823)$ $(t=23,633, p=0,000)$ değişkenler arasındaki ilişkinin istatistiksel olarak anlamlı olduğu tespit edilmiştir. Kariyer stresinin kariyer kararlılığ Diğer bir ifadeyle kariyer stresi kariyer kararlığı üzerindeki değişimin \% 74'ünü açıklamaktadır. 
Buradan $\mathrm{H}_{1}$ hipotezi reddedilememiştir, (Hı: Kariyer stresi kariyer kararlılığını etkilemektedir). Elde edilen bu değerlere göre aracılık rolünün tespiti için birinci adım yerine gelmiştir.

Aracılık testinin ikinci aşaması için kariyer stresinin (bağımsız değişken) sosyal ağ desteği (bağımlı değişken) üzerindeki etkisini belirlemek için regresyon analizi gerçekleştirilmiştir. Aracılık testi için bağımsız değişkenin (kariyer stresinin) bağımlı değişkeni (sosyal ağ desteği) anlamlı olarak $(\beta=-0,763, p<0,001)$ yordaması gerekli olan ikinci koşulu yerine getirmiştir. Kariyer stresinin, aracı değişken sosyal ağ desteğini negatif ve istatistiksel olarak anlamlı etkilediği görülmektedir. Kariyer stresinin sosyal ağ desteği üzerindeki $\mathrm{R}^{2}=0,477$ değerinin tespit edilmiş olması, kariyer stresinin sosyal ağ desteği üzerindeki değişimin \% 47'sini açıkladığı anlamını taşımaktadır. Bu sonuca göre; $\mathrm{H}_{2}$ hipotezi reddedilememiştir, $\left(\mathbf{H}_{2}\right.$ : Kariyer stresi sosyal ağ desteğini etkilemektedir). Aracılık testinin üçüncü koşulu olarak sosyal ağ desteğinin kariyer kararlılığına etkisi analize tabi tutulmuştur. El de edilen sonuçlara göre sosyal ağ desteğinin kariyer kararlılığı üzerinde pozitif ve anlamlı etkisi tespit edilmiştir. Bu sonuca göre de $\mathrm{H}_{3}$ hipotezi reddedilememiştir, (H3: Sosyal ağ desteği kariyer kararlılı̆̆ını etkilemektedir).

Aracılık testinin dördüncü ve son koşulu olarak aracı değişken (sosyal ağ desteği), modele girdiğinde bağımsız değişkenin (kariyer stresi), bağımlı değişken (kariyer kararlılığı) üzerindeki negatif etkisi $(\beta=-1,165, p<0,001)$, pozitif olarak değişmiş ve ters yönde artmıştır $(\beta=0,341$, $\mathrm{p}<0,001)$. Dördüncü koşulun analiz sonuçlarına göre sosyal ağ desteğinin, kariyer stresi ile kariyer kararlılı̆̆ 1 arasında önemli bir aracı değişken olduğunu göstermektedir. Bu sonuca göre $\mathrm{H}_{4}$ hipotezi reddedilememiş, ( $\mathbf{H}_{4}$ : Kariyer stresinin kariyer kararlılığını etkilemesinde sosyal ağ desteğinin aracılık rolü vardır). Sosyal ağ desteğinin kariyer stresi ve kariyer kararlılığı arasında aracılık yapacak önemli bir değişken olduğu ortaya konulmuştur.

Regresyon analizine ilişkin değerler için sobel testi yapılmıştır. Gerçekleştirilen sobel testinde anlamlılık ve sobel $(\mathrm{Z})$ değeri 4,45 olarak tespit edilmiştir. Bu sonuçlardan kariyer stresinin kariyer kararlılığı üzerinde anlamlı bir etkisinin olduğu, bu etkide sosyal ağ desteğinin önemli rol oynadığı tespit edilmiştir.

\section{SONUÇ}

Belirsizlik insan yaşamının her döneminde ortaya çıkan bir olgudur. Belirsizlik bilinir ile bilinmeyen arasındaki insanoğlunun aydınlatmaya çalıştığı muğlak alanı kapsamaktadır. Bireylerin geleceğe yönelik yaşamlarının muğlak alanlarından birisi de kariyer seçimi ve kariyer kararının verilmesi aşamasıdır. Bireylerin çoğunluğu bu aşamada nasıl bir karar vereceğini bilememenin vermiş olduğu belirsizlikler nedeniyle strese girebilmektedirler. Kariyer belirsizliği bireylerin yaşamları boyunca aynı şekilde belirli bir eğitim seviyesinden sonra belirli bir gelir seviyesine ulaşmak, toplum içerisinde saygınlık kazanmak ve daha fazla görünür tanınır olmak itibar görmek amacıyla elde etmek istediği konuma ne zaman ve ne şekilde ulaşılacağının bilinememesinden kaynaklanmaktadır. Özellikle kariyer basamağının ilk evresinde olan genç bireylerin günümüzde eğitim ve kariyer fırsatları konusunda büyük bir belirsizlikle karşı karşıya kaldıkları vurgulanmaktadır (Kalleberg vd., 2000, Mills ve Blossfeld, 2003). Bu durum eğitim hayatının sonuna yaklaşmış ve meslek yaşamına yeni başlamak üzere olan gençlerin tecrübesizliği nedeniyle üstesinden gelinmesi zor bir sorun haline dönüşmekte, kariyer belirsizliğine bağlı olarak kariyer stresi ortaya çıkmaktadır. Kariyer stresi bireylerin kariyer kararlılığını olumsuz etkilemektedir. Çalışmanın bulguları da bu bağlamda kariyer stresinin kariyer kararlılığını olumsuz etkilediğini ortaya koyarak literatürü desteklemekte ve kariyer stresinin genç yaştaki üniversite öğrencilerinin kariyer kararlarını negatif etkilediğini doğrulamaktadır. 
Literatürde de yapılan çalışmalarda sadece kariyer belirsizliğinden değil yaşam döngüsü içerisinde insanların karşı karşıya kaldığı birçok belirsizliğin başta sağlık olmak üzere olumsuz etkileri olduğu belirtilmektedir (Nagayoshi vd., 2014). Tüm bu olumsuzluklar karşısında özellikle genç bireyler kariyer kararlarını oluşturmak ve geleceğe yönelik planlarındaki muğlaklığı oltadan kaldırmak ve gelecek yaşam çizgilerindeki aşamaları daha belirgin kılmak istemektedirler. Bu maksatla sosyal ağları olarak nitelendirilen aile, eş, kardeş, arkadaş, meslektaş gibi gruplardan ve günümüzün en popüler iletişim araçları haline dönüşen sosyal medya hesaplarındaki sosyal ağlarındaki kişilerden gerek fikri gerekse maddi, manevi ve tavsiye desteği alma ihtiyacı duymaktadırlar. Çünkü yüksek sosyal statüdeki kişilerin zenginlik, güç ve diğer ağlara erişim gibi herkesin elde etmeyi arzuladığı imkânlara sahip olma olasıllı̆̆ diğerlerine göre her zaman daha yüksektir (Cross ve Cummings, 2004). Genç bireyler sosyal ağlarındaki bu tür kişilerin tecrübe ve bilgi birikimlerini, sosyal ve psikolojik rahatlatıcı telkinlerini, yol gösterici fikir ve düşüncelerini geleceğe yönelik yaşam çizgilerini oluşturacak kararların içerisine katarak kariyer kararlarını daha belirgin hale getirmektedirler. Genellikle sosyal ağlardan alınan bu çok yönlü destek bireylerin gelecek yaşamlarının şekillenmesine olumlu katkı sunmaktadır. Diğer bir ifadeyle belirsizliğin ortadan kaldırılması veya daha bilinir ve öngörülebilir olgular haline dönüştürülmesinde sosyal ağlardan alınan destek, bir taraftan kariyer stresini azaltırken diğer taraftan da kariyer kararlılı̆̆ının oluşumu üzerinde pozitif etki yapmaktadır. Disiplinler arasında sosyal destek, sadece kişilerarası yaşamda değil aynı zamanda fiziksel ve ruh sağlı̆̆ için de önemli olarak kabul edilmektedir (Kim, 2014). Bu bağlamda literatürde geçen sosyal ağ desteğinin insan yaşamına yaptığı pozitif katkı çalışmanın bulguları ile örtüşmektedir.

Makalenin temel savı bağımsız değişken kariyer kararlılığı ile bağımlı değişken kariyer stresi arasındaki mevcut ilişkide sosyal ağ desteğinin nasıl bir rol oynadığının ortaya konulmasıdır. Bu kapsamda yapılan kariyer stresi ile kariyer kararlılığı arasında sosyal ağ desteğinin aracilık rolünün tespitine yönelik hiyerarşik regresyon analizi sonuçlarına göre; regresyon analizinde aracılık testinin dördüncü ve son koşulu olarak aracı değişken (sosyal ağ desteği), modele dâhil edildiğinde bağımsız değişkenin (kariyer stresi), bağımlı değişken (kariyer kararlılığı) üzerindeki negatif etkisi $(\beta=-1,165, p<0,001)$, pozitif olarak değişmiş ve ters yönde artmıştır $(\beta=0,341$, $p<0,001)$. Bu sonuç bize sosyal ağ desteğinin söz konusu ilişkide güçlü bir aracı değişken olduğunu göstermektedir. Diğer bir ifadeyle sosyal ağ desteğinin, kariyer stresi ile kariyer kararlılığı arasında önemli bir aracılık görevi üstlendiği ortaya konulmuştur.

Çalışma belirli bir mesleğe yönelik kariyer belirsizliği ve stres algısını ölçmek üzere sadece İstanbul'daki üniversitelerin Gastronomi bölümünde öğrenim gören öğrencileri kapsamaktadır. $\mathrm{Bu}$ çerçevede düzenlenen anketlerin analiz sonuçlarına göre sosyal ağlardan alınan desteğin öğrencilerin kariyer stresini azaltarak kariyer kararlılığına olumlu katkı sunduğu ortaya konulmuştur. Çalışma bu bağlamda özellikle her yıl üniversiteler tarafından öğrencilerin kariyer gelişimini ve geleceğini şekillendirmek üzere düzenlenen "kariyer günleri" ve "kariyer konferanslarının" içeriğinin yeniden sorgulanmasına ışık tutacaktır. Çünkü kariyer kararlarının oluşumuna sağladığı katkı nedeniyle sosyal ağ desteği gibi önemli bir değişkenin üniversitelerin bu tür faaliyetlerin içeriğine dâhil edilmesi öğrencilerin geleceğe yönelik kariyer kararlarının oluşturulması ve kariyer streslilerinin azalması çabalarına yönelik alternatif fikir ve düşünce tarzlarının gelişimini sağlayacaktır. Çalışmadan elde edilen bulguların ileriki dönemlerde ulusal veya uluslararası seviyede farklı üniversitelerin farklı bölümlerindeki öğrenciler üzerinde gerçekleştirilecek çalışma sonuçları ile karşılaştırılması kariyer kararlarının oluşumu ve kariyer stresi ile ilgili alan yazına farklı bakış açıları sunabilir.

Gençlerin kariyer yolculuğu öncelikle meslek seçimi ile başlamaktadır ve meslek seçimi de bireyin eğitimi, yetenekleri, çevresi, kişisel özelliği, gibi birçok faktörden etkilenmektedir (Alkan, 2014: 63). İkinci aşamada kariyer basamaklarının oluşturulması için gerekli kariyer kararlarının 
verilmesi gelmektedir. Kariyer kararlarının verilmesi belirsizlik içeren zor ve stresli bir süreçtir. Kariyer stresi ve kararsızlığı içerisindeki gençlerin sosyal ağlarından alacakları desteğin gücü ve niteliği sosyal ağlarındaki kişilerin eğitim, yetenek, tecrübe ve ünlü olma gibi nitelikleri ile doğrudan ilişkilidir. Literatürde de sosyal ağların niceliğinden çok ilişki kalitesi, güven samimiyet gibi niteliğinin önemli olduğuna vurgu yapılmakta, sosyal ağlardaki ilişkilerin niteliksel üstünlügünün stres ve belirsizlikleri azaltarak depresyon ve inme riskini azalttığ1 vurgulanmaktadır (Chu vd., 2010; Teo vd., 2013; Nagayoshi vd., 2014). Bu bağlamda kariyer basamağının ilk aşamasındaki gençlerin sosyal ağları vasıtasıyla iletişime geçtikleri kişilerin etki ve nüfuz alanından sağladığı destek ile kariyer belirsizliklerinin çözümüne katkı sağlayabilirler. Ayrıca gençlere sosyal ağlarının niceliksel yönünden ziyade niteliksel yönüne odaklanmalarının gelecekte kariyer kararlarının oluşumuna pozitif katkı sunacağı önerilebilir. Üniversitelerin kariyer günlerinde öğrencilere nitelikli sosyal ağlarının nasıl oluşturulup geliştirilebileceği konusunda konferanslar verilerek bu alandaki boşluğun doldurulmasına katkı sunulabilir.

\section{KAYNAKÇA}

Akçakanat, T. ve Uzunbacak, H. H. (2019). Kariyer Kararlılığı Ölçeği: Türkçeye Uyarlama, Geçerlik ve Güvenirlik Çalışması, İktisadi İdari ve Siyasal Araştırmalar Dergisi, 4(9):159-170.

Alav, O. (2012). Sosyal Medya'nın Birey ve Toplumsal Yapıya Etkileri (Sosyal Medya Kullanıcı Araştırması). Elektronik Sosyal Bilgiler Ĕ̆itimi Dergisi, 1(1):1-22.

Alkan, N. (2014). Üniversite Adaylarının Bölüm Tercihleri: Bir Kariyer Araştırma Yöntemi Olarak Bölüm Tanıtımları. Türk Psikolojik Danışma ve Rehberlik Dergisi, 5(41):61-74.

Aliza W.S., Mohammad H. A., Cath C., Matthew S. and Tim S. (2017). The Relationship Between Social Support Networks and Depression in the 2007 National Survey of Mental Health and WellBeing, Soc Psychiatry Psychiatry Epidemiol, 52:1463-1473.

Ajrouch, K. J., Blandon, A. Y., and Antonucci, T. C. (2005). Social Networks Among Men and Women: The Effects of Age and Socioeconomic Status. Journal of Gerontology, 60, 311-317.

Aytaç, S. (2005). Çalışma Yaşamında Kariyer; Yönetimi, Planlaması, Gelişimi ve Sorunları. Bursa: Ezgi Kitabevi.

Berkman L. F, Glass, T, Brissette I. and Seeman T. E. (2000). From Social Integration to Health: Durkheim in the New Millennium. Soc Sci Med., 51(6):843-57.

Berkman, L.F. and Glass, T. (2000). Social Integration, Social Networks, Social Support, And Health. (Editör) Berkman L.F., Kawachi, I.: Social Epidemiology içinde. New York: Oxford University Press.

Blatný, M., Millová, K., Jelínek, M. and Osecká, T. (2015). Personality Predictorsof Successful Development: Toddler Temperamentand Adolescent Personality Traits Predict Well-Beingand Career Stabilityin Middle Adulthood. Plosone, 10(4):1-21, https://www.ncbi.nlm.nih.gov/pmc/articles/PMC4412673/pdf/pone.0126032.pdf.

Bubic, A. and Ivanisevic, K. (2016). The Role of Emotional Stability and Competence in Young Adolescents' Career Judgments, Journal of Career Development, 43(6):498-511.

Bynner, J. (2005). Rethinking the Youth Phase of The Life Course: The Case for Emerging Adulthood. Youth and Society, 8:367-384. 
Cacioppo, J.T., Hughes, M.E., Waite, L.J., Hawkley, L.C. and Thisted, R.A. (2006). Loneliness as A Specific Risk Factor for Depressive Symptoms: Cross-Sectional and Longitudinal Analyses. Psychol Aging, 21:140-151.

Kroenke, C. H., Marilyn L. K., Alfred I. N., Ergas, I. J., Wright, J. D., Caan, B. J., Hershman, D. and Kushi, L. H. (2013). Social Networks, Social Support Mechanisms, and Quality of Life After Breast Cancer Diagnosis, Breast Cancer Res Treat, 139:515-527.

Cavalca, G. G. (2018). The Shaky Social Citizenship of Early Career Independent Professionals: Work Transformation, Career and Life Uncertainty, Unrepresented Rights, Cambio, 8(16):183-195.

Chu P. S, Saucier D. A and Hafner, E. (2010). Meta-Analysis of The Relationships Between Social Support and Well-Being in Children and Adolescents. J Soc Clin Psychol, 29:624-645.

Connor-Smith, J. K., Flaschbart, C. (2007). Relations Between Personality a Dcoping: AmetaAnalysis, J Pers Soc Psychol 93:1080-1107.

Creed, P. A., Prideaux, L. A., and Patton, W. (2005). Antecedents and Consequences of Career Decisional States in Adolescence. Journal of Vocational Behavior, 67:397-412.

Cross, R. and Cummings, J. N. (2004). Tie and Network Correlates of Individual Performance in Knowledge-Intensive Work. The Academy of Management Journal, 47:928-937.

Cüceloğlu, D. (1992). İnsan ve Davranışı. İstanbul: Remzi Kitapevi.

Daniels, L. M., Stewart, T. L., Stupnisky, R. H., Perry, R. P. and LoVerso, T. (2011). Relieving career anxiety and indecision: The Role of Undergraduate Students Perceived Control and Faculty Affiliations, Social Psychology of Education, 14:409-426.

Danziger, S., and Ratner, D. (2010). Labor Market Outcomes and The Transition to Adulthood, The Future of Children, 20:133-158.

Davis, A., Kimball, W., and Gould, E. (2015). The Class Of 2015: Despite an Improving Economy, Young Grads Still Face an Uphill Climb. Economic Policy Institute (Report).

De Cuyper N., De Witte H. and Van Emmerik, H. (2011). Temporary Employment: Costs and Benefits For (The Careers Of) Employees and Organizations, Career Development International, 16:104-113.

Derr, C. B. (1986). Managing the New Careerists. San Francisco: Jossey-Bass.

Doorewaard, H., J. Hendrickx, and P. Verschuren. (2004). Work Orientations of Female Returners. Work, Employment and Society 18(1):7-27.

Doubova Dubova, S. V., Perez-Cuevas, R., Espinosa-Alarcon, P., and Flores-Hernandez, S. (2010). Social Network Types and Functional Dependency in Older Adults in Mexico, BMC Public Health, 10/104:1-10.

Driver, M.J., and Coombs M., (1983). Fit Between Career Concepts, Corporate Culture, And Engineering Productivity and Morale. Proceedings of IEEE Conference on Enhancing Engineering Careers, Palo Alto, CA: 27 October, 12-22.

Duffy, R. D., Blustein, D. L., and Diemer, M. A. (2016). The psychology of working theory. Journal of Counseling Psychology, 63:127-148.

Edwin, T.R., Polly, P. and Jorgen, S. (2019). How Uncertainty Affects Career Behaviour: A Narrative Approach, Australian Journal of Management, 44(1):50-69. 
Fetherston M., Cherney M. R. and Bunton T. E. (2018). Uncertainty, Technology Use and Career Preparation Self-Efficacy, Western Journal of Communication, 82:3:276-295.

Gati I., Garty, Y., and Fassa, N. (1996). Using Career-Related Aspects to Assess PersonEnvironment Fit, Journal of Counseling Psychology, 43:196-206.

Gati, I. (1998). Using Career-Related Aspects to Elicit Preferences and Characterize Occupations for A Better Person-Environment Fit, Journal of Vocational Behavior, 52:343-356.

Gati, I., Landman, S., Davidovitch, S., Asulin-Peretz, L., and Gadassi, R. (2010). From Career Decision-Making Styles to Career Decision-Making Profiles: A Multidimensional Approach, Journal of Vocational Behavior, 76:277-291.

Gati, I. and Levin, N. (2012). The Stability and Structure of Career Decision-Making Profiles: A 1Year Follow-Up, Journal of Career Assessment 20(4):390-403.

Gati, I. and Gutentag T., (2015). The Stability of Aspect- Based Career Preferences and of the Recommended List of Occupations Derived from Them, Journal of Vocational Behavior, 87:11-21.

Gattiker, U. E., and Larwood, L. (1989). Corporate Managers. The Social Science Journal 26(1):7592.

Germeijs, V., and De Boeck, P. (2002). A Measurement Scale for Indecisiveness and Its Relationship to Career Indecision and Other Types of Indecision. European, Journal of Psychological Assessment, 18:113-122.

Gielen, A. C., McDonnell, K. A., Wu, A. W., O'Campo, P., and Faden, R. (2001). Quality of Life Among Women Living With HIV: The Importance of Violence, Social Support, and Self Care Behaviors. Social Science and Medicine, 52:315-322.

Greenhaus, J. H., Callanan, G. A., and Kaplan, E. (1995). The Role of Goal Setting in Career Management. International Journal of Career Management, 7(5):3-12.

Goyanes, M. and Rodríguez-Gómez, E. F. (2018). Presentism in The Newsroom: How Uncertainty Redefines Journalists' Career Expectations, Journalism 00(0), ss. 1-17, DOI: $10.1177 / 1464884918767585$.

Gutman, L.M. and Schoon, I. (2012). Correlates and Consequences of Uncertainty in Career Aspirations: Gender Differences Among Adolescents in England, Journal of Vocational Behavior, 80:608-618.

Hall, D. T. and Kahn, W. A. (2002). Developmental Relationships at Work: A Learning Perspective. (Editör) Cooper C. L. and Burke R. J.: The New World of Work: Challenges and Opportunities içinde (s. 49-74). Oxford: Blackwell Publishers.

Heppner, P. P. (2008). Expanding the Conceptualization and Measurement of Applied Problem Solving and Coping: From Stages to Dimensions to The Almost Forgotten Cultural Context. American Psychologist, 63:803-816.

Jaskolka, G., J. Beyer, and Trice, H. (1985). Measuring and Predicting Managerial Success. Journal of Vocational Behavior, 26:189-205.

Jokela, M., Hintsa, T., Hintsanen, M. and Keltikangas-Jarvinen, L. (2010). Adult Temperament and Child Bearing Overthelifecourse. EurJPersonality, 24:151-166.

Kawachi, I. and Berkman, L. F. (2001). Social Ties and Mental Health. J Urban Health, 78:458-467.

Kelly, M. E., Duff, H., Kelly, S., Joanna, E., McHugh, P., Sabina, B., Brian, A. L. and Loughrey, D.

G (2017). The Impact of Social Activities, Social Networks, Social Support and Social 
Relationships on The Cognitive Functioning of Healthy Older Adults: A Systematic Review, Systematic Reviews, 6(259):1-18.

Kim, H. (2014). Enacted Social Support on Social Media and Subjective Well-Being. International Journal of Communication, 8:2201-2221.

Körner A., Lchner, C. M., Pavlova, M. K. and Silbereisen, R. K. (2015). Goal Engagement in Coping with Occupation Uncertainty Predict Favorable Career-Related Outcomes, Journal of Vocational Behavior, 88:174-184.

Krumboltz, J. D. (1979). A Social Learning Theory of Career Decision Making. In Social Learning and Career Decision Making, (Editör) A.M. Mitchell, G.B. Jones, and J.D. Krumboltz, 19-49.

Law, A. K., Amundson, N. E., Alden and Lynn E. (2014). Helping Highly Anxious Clients Embrace Chaos and Career Uncertainty Using Cognitive Behavioural Techniques, Australian Journal of Career Development, Vol. 23(1):29-36.

Lin, S., Wu, C. and Chen, L. H. (2015). Unpacking the Role of Self-Esteem in Career Uncertainty: A Self-Determination Perspective, The Journal of Positive Psychology, 10(3):231-239.

Loughlin, C., and Barling J. (2001). Young Workers' Work Values, Attitudes, And Behaviors. Journal of Occupational and Organizational Psychology, 74(4):543-58.

Lounsbury, J. W., Tatum, H. E., Chambers, W., Owens, K., and Gibson, L. W. (1999). An Investigation of Career Decidedness in Relation To "Big Five" Personality Constructs and Life Satisfaction. College Student Journal, 33(4):646-652.

MacGeorge, E. L., Feng, B., and Burleson, B. R. (2012). Supportive Communication. (Editör) M. L. Knapp and J. A. Daly, The SAGE Handbook of Interpersonal Communication içinde (s. 317354). Thousand Oaks, CA: SAGE.

McElroy, J. C. and Weng, Q. (2016). The Connections Between Careers and Organizations in The New Career Era. Journal of Career Development 43: 3-10.

Miguel, M. M. (1993). Individual Definitions Of Career Success: At Odds with Organizational and Social Definitions. Doctoral diss., University of North Carolina at Chapel Hill (Dissertation Abstract International 7A54, no. 4: 1456).

Mıles, J. (2016). Organizasyon Kuramları, (Çeviren, Polat, M., Arun, K.) Ankara: Nobel Yayıncllık.

Nagayoshi, M., Everson-Rose, S. A. I., Hiroyasu, M. D., Mosley, T. H. Jr, R., Kathryn M., L. and Pamela, L. (2014). Social Network, Social Support, and Risk of Incident Stroke: The Atherosclerosis Risk in Communities Study, Ovid, 45(10):2868-2873.

Namhee, K. and Gary, N. M. (2008). Stability and Dominance in Career Success Orientation in South Korean Employees, Human Resource Development International, 11(1):19-34.

Özden, K. ve Sertel, B. Ö. (2017). Kariyer Stresi Ölçeğinin (KSÖ) Türkçe'ye Uyarlanması ve Psikometrik Özelliklerinin Sınanması, Psikoloji Çalışmaları Dergisi, 37(1):35-51.

Park, S., Smith, J., and Dunkle, R. E. (2014). Social Network Types and Well-Being Among South Korean Older Adults. Aging Ment Health, 18(1):72-80.

Pryor, R. G. L., Amundson, N. E., and Bright, J. E. H. (2008). Probabilities and Possibilities: The Strategic Counseling Implications of the Chaos Theory of Careers. The Career Development Quarterly, 56(4):309-318. 
Pryor, R. G. L., and Bright, J. E. H. (2008). Archetypal Narratives in Career Counselling: A Chaos Theory Application. International Journal for Educational and Vocational Guidance, 8:71-82. doi:10.1007/s10775-008-9138-8.

Pryor, R. G. L., and Bright, J. E. H. (2011). The Chaos Theory of Careers: A New Perspective on Working in The Twentyfirst Century. New York, NY: Routledge.

Pryor, R. G. L. and Bright, J. E. H. (2012). The Value of Failing in Career Development: A Chaos Theory Perspective. International Journal for Educational and Vocational Guidance, 12:67-79. doi:10.1007/s10775011-9194-3.

Reinardy, S. (2011). Newspaper Journalism in Crisis: Burnout on The Rise, Eroding Young Journalists Career Commitment. Journalism, 12(1):33-50.

Restubog, S. L. D., Florentino, A. R., and Garcia, P. R. J. M. (2010). The Mediating Roles of Career Self-Efficacy and Career Decidedness in The Relationship Between Contextual Support and Persistence. Journal of Vocational Behavior, 77(2):186-195.

Sadler, P. M., Sonnert, G., Hazarı, Z. and Tai, R. (2012). Stability and Volatility of Stem Career Interest in High School: A Gender Study, Science Education, 96(3):411-427.

Saka, N., and Gati, I. (2007). Emotional and Personality-Related Aspects of Persistent Career Decision-Making Difficulties. Journal of Vocational Behavior, 71:340-358.

Santos, P. J. (2001). Predictors of Generalized Indecision Among Portuguese Secondary School Students. Journal of Career Assessment, 9:381-396.

Sarajärvi, A., Haapamäki, M. L., and Paavilainen, E. (2006). Emotional and Informational Support for Families During Their Child's Illness. International Nursing Review, 53(3):205-210.

Scott, S.G., and Bruce, R. A. (1995). Decision-making Style: The Development and Assessment of a New Measure. Educational and Psychological Measurement, 55:818-831.

Shea, M., Ma, P. W. W., Yeh, C. J., Lee, S. J. and Pituc, S. T. (2009). Exploratory Studies on The Effects of a Career Exploration Group for Urban Chinese Immigrant Youth. Journal of Career Assessment, 17:457-477.

Shin-Huei, L., Chia-huei, W. and Lung Hung, C. (2015). Unpacking the Role of Self-Esteem in Career Uncertainty: A Self-Determination Perspective, The Journal of Positive Psychology, 10(3):231-239.

Shiner, R. L. and Caspi, A. (2012). Temperament and The Development of Personality Traits, Adaptations, And Narratives (s.497-516). (Editör) Zentner, M., Shiner, R. L.: Handbook of Temperament. NewYork, London: The GuilfordPress.

Skrbiš, Z. and Laughland-B., J. (2019). Technology, Change, And Uncertainty: Maintaining Career Confidence in The Early 21st Century, New Technology, Work and Employment, 34(3):191-207.

Sully de Luque, M., and Javidan, M. (2004). Uncertainty Avoidance. (Editör) R. M. House, P. J. Hanges, M. Javidan, P. W. Dorfman, V. Gupta, and G. Associates: Leadership, Culture, And Organizations: The GLOBE Study Of 62 Societies içinde (s. 602-653). Thousand Oaks, CA: Sage.

Sun K.L., Kim H., and Cameron W. P., (2019). The Role of Status Differentials and Homophily in the Formation of Social Support Networks of a Voluntary Organization, Communication Research, 46(2):208-235. 
Specht, J., Egloff, B., and Schmukle, S. C. (2011). Stability and Change of Personality Across the Life Course: The Impact of Ageand Majör Life Events on Mean-Leveland Rank-Order Stability of The Big Five. J Pers Soc Psychol, 101:862-882.

Tardy, C. H. (1985). Social Support Measurement. Am J Commun Psychol, 13:187-202.

Teo, A. R, Choi, H., Valenstein, M. (2013). Social Relationships and Depression: 10-Year FollowUp from A Nationally Representative Study. PLoS One, 8(4): e62396.

Turner, H. A., and Butler, M. J. (2003). Direct and Indirect Effects of Childhood Adversity on Depressive Symptoms in Youth Adults. Journal of Youth and Adolescence, 32:89-103.

Trevor-Roberts E., Parker P. and Sandberg, Jorgen. (2019). How Uncertainty Affects Career Behaviour: A Narrative Approach, Australian Journal of Management, 44(1):50-69.

Uchino, B. N. (2009). What A Lifespan Approach Might Tell Us About Why Distinct Measures of Social Support Have Differential Links to Physical Health, Journal of Social and Personal Relationships, 26(1):53-62.

Uthayakumar, R., Schimmack, U., Hartung, P. J., and Rogers, J. R. (2010). Career Decidedness as a Predictor of Subjective Well-Being. Journal of Vocational Behavior, 77(2):196-204.

Uzakgiden, A. M. ve Erözkan, A. (2019). Sosyal Ağlarda Sosyal Destek Beklentisi: Ölçek Geliştirme, Güvenirlik ve Geçerlik Çalışması. Ege Bilimsel Araştırmalar Dergisi, 2(1):20-33. 